\title{
A RARE PRESENTATION OF MUSCULOSKELETAL TUBERCULOSIS: TENOSYNOVITIS OF THE FLEXOR TENDONS OF THE WRIST AND DIGITS
}

\author{
MUSKULOSKELETAL TÜBERKÜLOZUN NADIR BIR FORMU: EL BILEĞi VE PARMAK \\ FLEKSÖR TENOSINOVITI
}

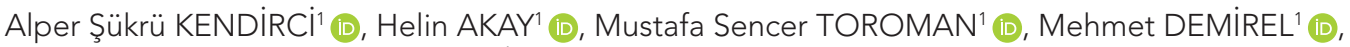 \\ Taha KIZILKURT'1 iD, Ömer Naci ERGIN ${ }^{1}$ \\ ${ }^{1}$ Istanbul University, Istanbul Faculty of Medicine, Departments of Orthopedicis and Traumatology, Istanbul Turkey
}

ORCID IDs of the authors: A.Ş.K. 0000-0001-6250-2469; H.A. 0000-0002-3385-3443; M.S.T. 0000-0003-2977-3624;

M.D. 0000-0003-1131-7719; T.K. 0000-0001-9832-8140; Ö.N.E. 0000-0001-6848-6930

Cite this article as: Kendirci AS, Akay H, Toroman MS, Demirel M, Kizilkurt T, Ergin ON. A Rare presentation of musculoskeletal tuberculosis: tenosynovitis of the flexor tendons of the wrist and digits. J Ist Faculty Med 2020;83(4):446-50. doi: 10.26650/IUITFD.2020.0048

\begin{abstract}
One of the extrapulmonary mycobacterium tuberculosis infection is wrist tenosynovitis and treatment of the wrist tenosynovitis includes antibiotics and surgical debridement. We report the diagnosis and treatment of a patient with tuberculosis tenosynovitis of the flexor tendons of the wrist and digits. Our patient was 65 years old. In his physical examination, swelling, redness, and warming along the wrist and draining open wounds on the palmar surfaces of the first and fifth fingers at the same hand were detected. In the laboratory tests, his acute-phase reactants had increased and in the T2A series, MRI findings depicted millimetric nodular images on the sheath of the flexor tendons of the wrist and first and fifth digits, which were consistent with synovitis. Debridement and synovectomy of flexor tendons of the wrist and D1, D5 of the left side was performed. A total of 6 months of a rifampicin-based anti-tuberculosis treatment was administered. In the second year after the operation, there was no problem with previous wound, and range of motion and muscle strength of the fingers and wrist joint were complete.
\end{abstract}

Keywords: Tuberculosis tenosynovitis, musculoskeletal, flexor, wrist

\section{ÖZET}

Ekstrapulmoner Mycobacterium Tuberculosis enfeksiyonlarından biri el bileği fleksör tenosinovitidir. Tedavisi antibiyoterapi ve cerrahi debridmandır. Bu vaka sunumunda; el bileği ve parmak fleksör tendon tüberkülozu olan bir hastanın tanı ve tedavi süreci anlatılmaktadır. Hastamız 65 yaşındaydı, fizik muayenesinde şişlik, kızarıklık ve el bileğinde ısı artışı ile birlikte birinci ve beşinci parmakların palmar yüzlerinde drene açık yaralar mevcuttu. Laboratuvar testlerinde akut faz reaktanları yüksekti ve MRG bulguları T2A serisinde el bileği ve D1, D5 parmak fleksör tendonlarının kılıflarında sinovit ile uyumlu milimetrik nodüler görüntüler mevcuttu. Sol el bileği ve D1, D5 fleksör tendonlarının debridmanı ve sinovektomi işlemi yapıldı. Ameliyattan sonra 6 ay süre ile rifampisin bazlı anti-tüberküloz tedavi uygulandı. Ameliyat sonrası 2. yılda hastanın yara yeri problemi yoktu, el ve parmak eklem hareket açıkıkları ve kas gücü tamdı.

Anahtar Kelimeler: Tüberküloz tenosinovit, muskuloskeletal, fleksör, el bileği

Corresponding author/iletişim kurulacak yazar: alpersukru@gmail.com

Submitted/Başvuru: 03.05.2020 • Revision Requested/Revizyon Talebi: 28.05.2020 •

Last Revision Received/Son Revizyon: 07.07.2020 • Accepted/Kabul: 09.07.2020 • Published Online/Online Yayın: 02.10.2020

(C)Telif Hakkı $2020 \mathrm{~J}$ Ist Faculty Med - Makale metnine jmed.istanbul.edu.tr web sayfasından ulaşılabilir.

(C) Copyright 2020 by J Ist Faculty Med - Available online at jmed.istanbul.edu.tr 


\section{INTRODUCTION}

Tuberculosis infection, mainly caused by Mycobacterium Tuberculosis, continues to be a significant health problem worldwide. Although the infection primarily affects the lungs, it can affect extrapulmonary tissues such as the musculoskeletal system (1). In 2018, there were an estimated 7 million new and relapse tuberculosis (TB) cases worldwide. The rate of extrapulmonary tuberculosis is around $15 \%$ in the 7.0 million incident cases (2). Musculoskeletal tuberculosis accounts for $10 \%$ of extrapulmonary tuberculosis cases in the USA, and the most commonly affected musculoskeletal areas are the spine, pelvis, and long bones of the lower limb (3). However, tuberculosis tenosynovitis of the flexor tendons of the wrist and digits constitutes an uncommon condition with only a limited number of cases reported in the literature.

This case report aimed to describe the clinical and radiological features of a rare case of tuberculous tenosynovi- tis of the digits and wrist flexors and to illustrate the medical and surgical treatment planning in the management of this rare manifestation of extrapulmonary tuberculosis.

\section{CASE REPORT}

A male aged 65 years was admitted to our department with pain, redness, and swelling in the volar side of his left wrist. His medical history revealed that the symptoms started 1 year ago. Once the pain became too intense, the patient applied to the rheumatology department. After a thorough investigation in terms of rheumatologic diseases was carried out, the patient was referred to our department.

In his physical examination; swelling, redness, and warming along the wrist and draining open wounds on his palmar faces of the first and fifth fingers at the same hand were determined (Figure 1-A). Laboratory tests revealed $19.76 \mathrm{mg} / \mathrm{L}$ of C-reactive protein (CRP), $21 \mathrm{~mm} / \mathrm{h}$ of eryth-
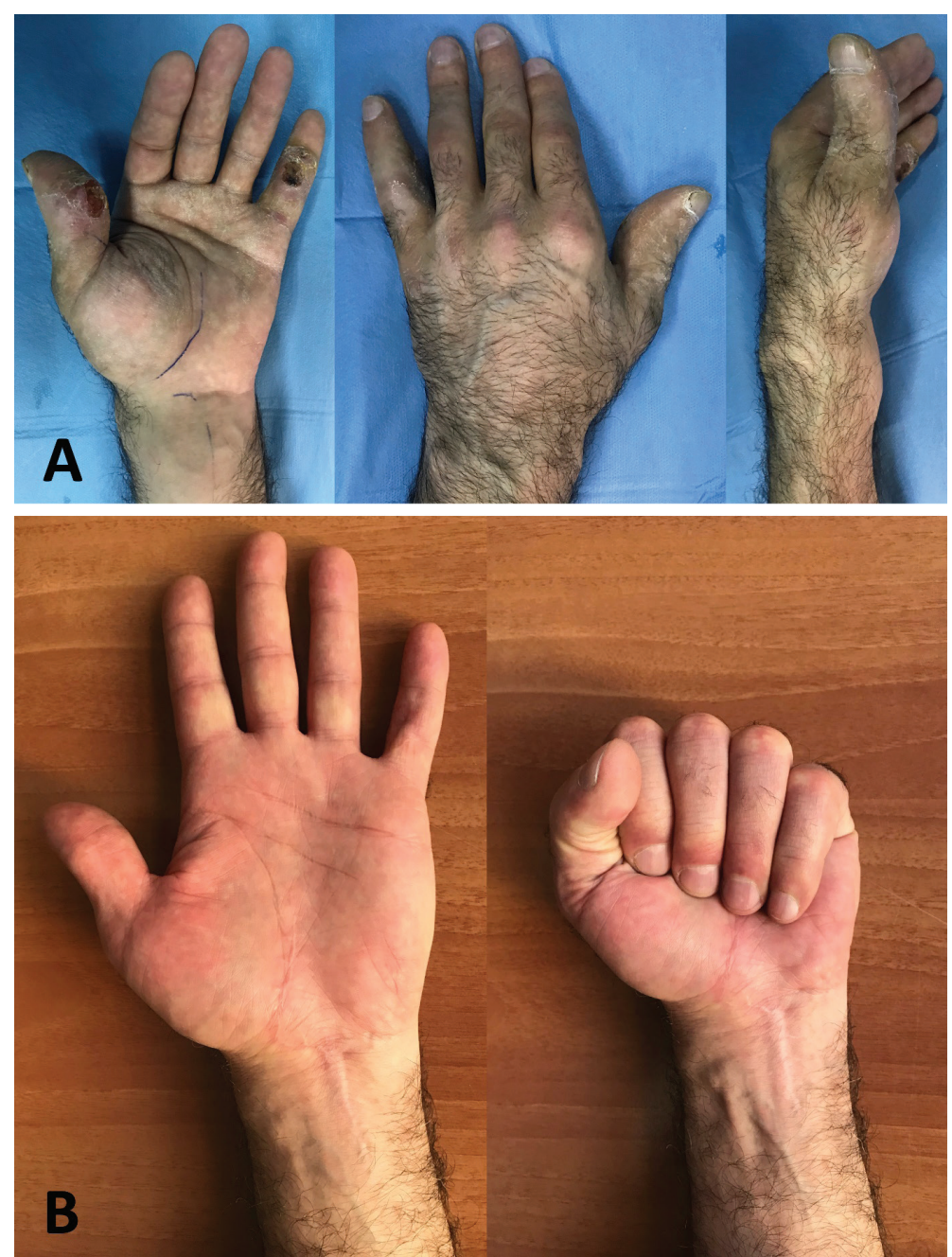

Figure 1-A: Swelling and redness in the wrist along with draining open wounds on palmar faces of the first and fifth fingers, B: Postoperative second year, no wound problem and full range of motion of wrist and digits. 
rocyte sedimentation rate (ESR), and $7.5 \times 10^{3} \mathrm{~mm}^{3}$ of white blood cells (WBC). In the radiological examination, a wrist X-ray was undertaken, which displayed a remarkable increase in the soft tissue density with periarticular osteoporosis (Figure 2-A). Additionally, magnetic resonance imaging (MRI) depicted millimetric nodular images on sheaths of flexor tendons of the wrist and D1, D5 digits in the T2A series, which were consistent with synovitis (Figure 3-A). Then, the decision for biopsy was made, additional workup including PPD test and chest radiography was undertaken. PPD was $18 \mathrm{~mm}$ and chest radiography showed no clinically significant finding. Pathologic examination revealed necrotizing granulomatous inflammation with central abscess. Additionally, in the microbiologic examination, $\mathrm{m}$. tuberculosis was derived from the Lowenstein Jensen medium.

In light of the aforementioned findings, the diagnosis of tuberculosis tenosynovitis was established, and the surgical debridement was planned. Informed consent about the surgery was achieved from the patient. At the operating room, left wrist flexor tendon synovectomy and D1, D5 flexor tendon synovectomy were performed under an axillary block. During the operation, the transverse carpal ligament was released, and the median nerve was protected. Synovial hypertrophy was seen in the flexor tendons' sheath at the wrist and first-fifth digital (Figure 4). All synovia was debrided, and tissue examples were sent to the laboratory for culture and pathological diagnosis. After the operation, oral rifampicin-based anti-tuberculosis treatment was continued for six months. Extension exercises for wrist and digitals were applied to the patient for musculoskeletal rehabilitation.

Six months later, there was no synovitis in the MRI (Figure $3-B)$ and there was no periarticular osteoporosis in the $\mathrm{x}$-ray examination (Figure 2-B), and the second year after the operation, there was no problem with the previous wound and, range of motion and muscle strength of the fingers and wrist joint were complete (Figure 1-B).

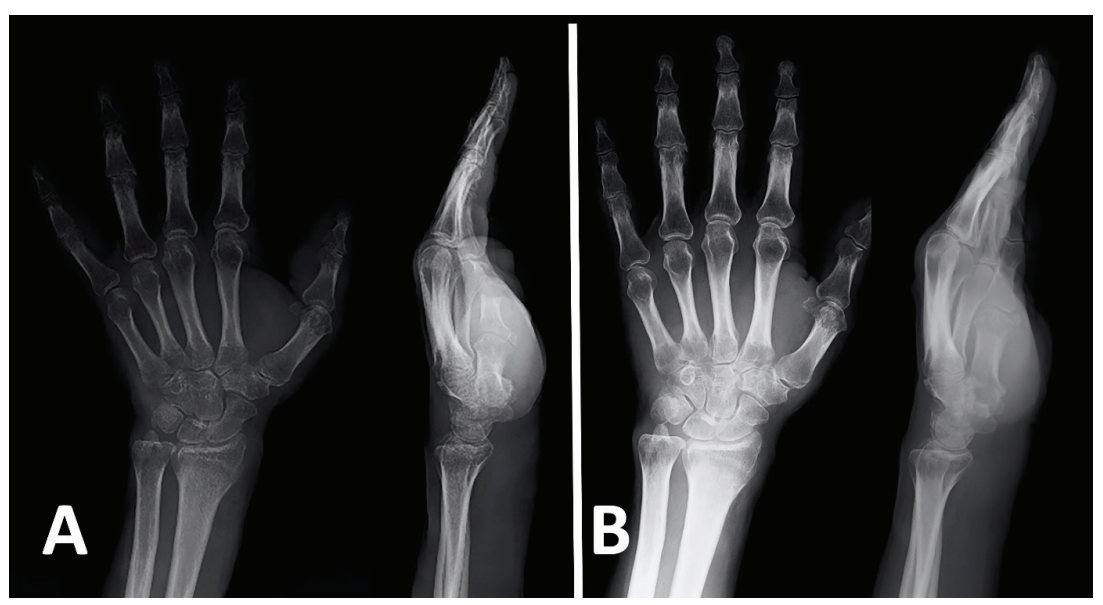

Figure 2-A: Preoperative wrist $x$-ray, increase in the soft tissue density with periarticular osteoporosis, B: Postoperative sixth month wrist x-ray.
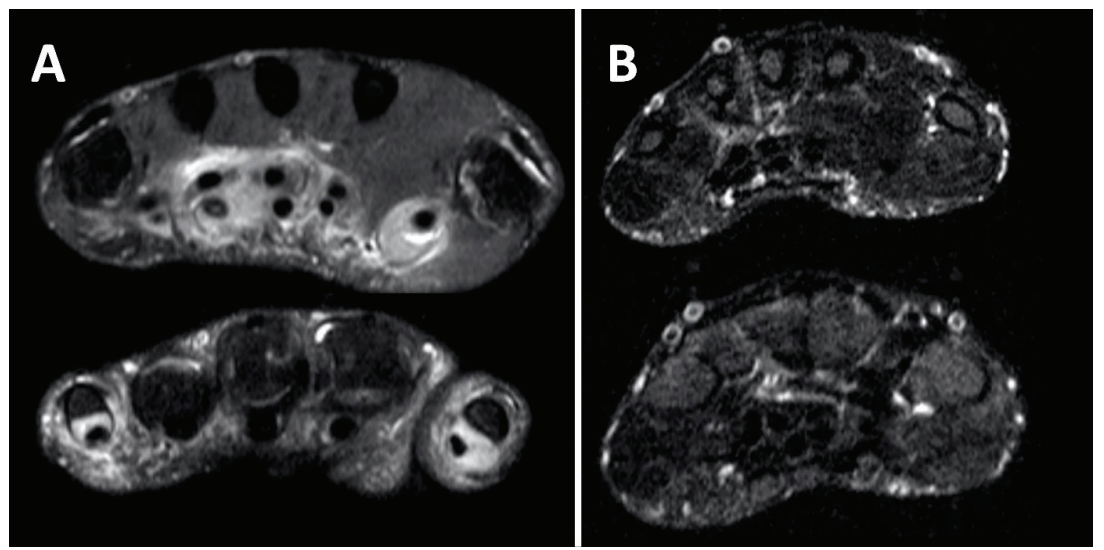

Figure 3-A: Preoperative MRI, T2A sequence axial view, millimetric nodular images on sheaths of flexor tendons of the wrist and D1, D5 digits, B: Postoperative sixth month MRI, T2A sequence axial view. 


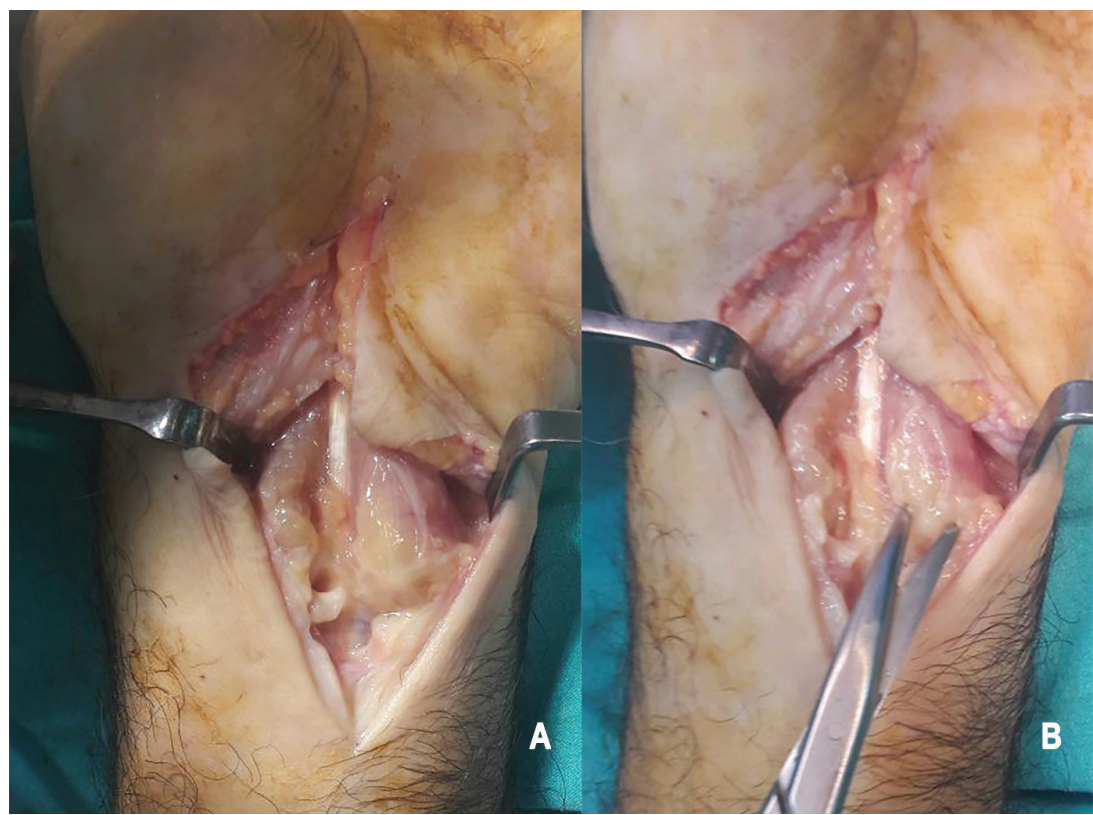

Figure 4-A: Intraoperative view, B: Rice bodies around the wrist flexor tendons.

\section{DISCUSSION}

Musculoskeletal tuberculosis infection can affect the vertebra, pelvis, and wrist, as well. Although rare, the involvement of the tendon sheath is possible and generally secondary to hematogenous spread (4).

Following the invasion of the tuberculosis bacteria into the tissue, tissue exudation and granulation may occur. As a result of the progression of inflammation, rice bodies can be seen. Woon et al. stated that during the surgery, the appearance of Rice stems, millet seeds or melon seeds suggest a high rate of tuberculosis tenosynovitis (5). In individuals with the involvement of tendon sheath, symptoms are typically non-specific such as swelling and pain; hence, it can be diagnosed late because of the dearth of systemic findings. Furthermore, some patients may manifest with the findings of carpal tunnel syndrome (6). The diagnosis of musculoskeletal tuberculosis can be overlooked, with the average time from onset of symptoms to diagnosis is 16-19 months (7). In our patient, the diagnosis was established 12 months later, and the first clinical and radiographic findings led to the diagnosis of seronegative arthritis. In the presence of tenosynovitis, wrist $\mathrm{X}$-ray may have an ability to display soft tissue swelling and osteoporotic bony changes around the wrist joint. However, T2-weighted sequences on MRI support the diagnosis better. In T2-weighted sequences, central erosion and peripheral abscesses, along with hypointense focus and synovia, distinguish tuberculosis from other types of inflammatory arthritis $(8,9)$. In our case, we have observed similar changes in soft tissue and carpal bones.
According to Kanavel, involvement of the tendon sheath in tuberculosis consists of three stages. In the first stage, severe serous exudation occurs after sheath thickening The second stage is the proliferative phase of granulomatous tissues leading to the rice bodies, and in the last stage, necrosis occurs (10). In our patient, the diagnosis was established in the second stage of the disorder.

In the management of tuberculosis, antituberculosis drugs are a treatment of choice. Surgical treatment only confers symptomatic relief. However, surgical treatment can be effective in people diagnosed at stage 2 or 3 . Benchakroum et al gave antituberculosis drug treatment to $11 \mathrm{pa}-$ tients with wrist tuberculosis, but medical treatment failed in patients with abscess and applied surgery to them (11). Treatment becomes difficult in patients with rice bodies, because debridement is required to complete treatment and prevent recurrence. It is also recommended to remove all bursas in the appearance of the rice body.

\section{CONCLUSION}

Tuberculosis tenosynovitis is a rare disease. However, it can be diagnosed with detailed physical examination and imaging. Although surgical debridement is required after the diagnosis, anti-tuberculosis oral therapy is necessary for the recovery and prevention of recurrence.

Ethics Committee Approval: This study was not approved by an ethical committee. (Case Report)

Informed Consent: Written consent was obtained from the participants. 
Peer Review: Externally peer-reviewed.

Author Contributions: Conception/Design of Study- A.Ş.K., M.D.; Data Acquisition- A.Ş.K., H.A., M.S.T.; Data Analysis/Interpretation- A.Ş.K., M.D.; Drafting Manuscript- A.Ş.K., H.A., M.S.T.; Critical Revision of Manuscript- M.D., T.K.; Final Approval and Accountability- A.Ş.K, H.A., M.S.T., M.D., T.K., Ö.N.E.

Conflict of Interest: Authors declared no conflict of interest.

Financial Disclosure: Authors declared no financial support.

Etik Komite Onayı: Etik komite onayı alınmamıştır. (Olgu sunu$\mathrm{mu})$.

Bilgilendirilmiş Onam: Katılımcılardan bilgilendirilmiş onam alınmıştır.

Hakem Değerlendirmesi: Dış bağımsız.

Yazar Katkıları: Çalışma Konsepti/Tasarım- A.Ş.K., M.D.; Veri Toplama- A.Ş.K., H.A., M.S.T.; Veri Analizi/Yorumlama- A.Ş.K., M.D.; Yazı Taslağı- A.Ş.K., H.A., M.S.T.; İçeriğin Eleştirel İncelemesi- M.D., T.K.; Son Onay ve Sorumluluk- A.Ş.K, H.A., M.S.T., M.D., T.K., Ö.N.E.

Çıkar Çatışması: Yazarlar çıkar çatışması beyan etmemişlerdir.

Finansal Destek: Yazarlar finansal destek beyan etmemişlerdir.

\section{REFERENCES}

1. Sandgren A, Hollo V, Van der Werf MJ. Extrapulmonary tuberculosis in the European Union and European economic area, 2002 to 2011. Eurosurveillance 2013;18(12):20431.
2. Annabel B, Anna D, Hannah M. Global tuberculosis report 2019. Geneva: World Health Organization; 2019.p.7-9.

3. Leonard MK, Blumberg HM. Musculoskeletal Tuberculosis. In: Tuberculosis and Nontuberculous Mycobacterial Infections, D. Schlossberg (Ed.). 2017.p.371-392. [CrossRef]

4. Bayram S, Erşen A, Altan M, Durmaz H. Tuberculosis tenosynovitis with multiple rice bodies of the flexor tendons in the wrist: a case report. Int J Surg Case Rep 2016;27:12932. [CrossRef]

5. Woon CY-L, Phoon E-S, Lee JY-L, Puhaindran ME, Peng Y-P, Teoh L-C. Rice bodies, millet seeds, and melon seeds in tuberculous tenosynovitis of the hand and wrist. Ann Plast Surg 2011;66(6):610-7. [CrossRef]

6. Kang HJ, Park SY, Shin SJ, Kang ES, Hahn SB. Tuberculous tenosynovitis presenting as carpal tunnel syndrome. J Korean Soc Surg Hand 2000;5:137-141.

7. Lee SH, Abramson SB. Infections of the musculoskeletal system by M. tuberculosis. In: Rom WN, Garay SM, eds. Tuberculosis. New York, NY: Little, Brown and Company, 1996. p.635-644.

8. Hsu C-Y, Lu H-C, Shih TT-F. Tuberculous infection of the wrist: MRI features. Am J Roentgenol 2004;183(3):623-8. [CrossRef]

9. Sawlani V, Chandra T, Mishra RN, Aggarwal A, Jain UK, Gujral RB. MRI features of tuberculosis of peripheral joints. Clin Radiol 2003;58(10):755-62. [CrossRef]

10. Kanavel AB. Tuberculous tenosynovitis of the hand: a report of fourteen cases of tuberculous tenosynovitis. Surg Gynecol Obstet 1923;37:635-47.

11. Benchakroun $M$, Bardouni A El, Zaddoug $O$, Kharmaz $M$, Yaacoubi M El, Ouadghiri M, et al. Tuberculosis of the wrist. Symptoms and outcome in eleven cases. Rev Chir Orthop Reparatrice Appar Mot 2004;90(4):337-45. [CrossRef] 